Botany.-The Desmazières prize ( 1600 francs), for a publication on cryptogams; the Montagne prize (I500 francs), for important works bearing on the anatomy, physiology, development, or description of the lower cryptogams; the de Coincy prize (900 francs), for a work on phanerogams; the Thore prize (200 francs), for the host work on the cellular cryptogams of Europe.

Anatomy and Zoology.- The Savigny prize (1500 francs), for the assistance of young travelling zoologists, not in receipt of Government assistance, who occupy themselves more especially with the invertebrates of Egypt and Syria; Grand prize of the physical sciences (3000 francs), for the morphogenic study of the characters of aclaptation to tree? life in the vertebrates; the. Cuvier prize (I500 francs), for a work on zoological palxontology, comparative anatomy, or zoology.

Medicine and Surgery.-Montyon prize (2500 francs, mention of 1500 francs); the Barbier prize (2000 francs), for a valuable discovery in surgical, medical, or pharmaceutical science, or in botany in its relation to medicine; the Bréant prize (100,000 francs), for discovering a cure for Asiatic cholera, or by discovering and removing its cause; the Godard prize (Iooo francs), for the best memoir on the anatomy, physiology, and pathology of the genitourinary organs; the Baron Larrey prize ( $75^{\circ}$ francs), for an army or navy surgeon or physician for the best work dealing with the subject of military medicine, surgery, or hygiene; the Bellion prize ( 1400 francs); the Mege prize (10,000 francs); the Chaussier prize (10,000 francs), for the best book or memoir on practical or forensic medicine.

Physiology.-A Montyon prize ( 750 francs), for experimental physiology; the Philipeaux prize (900 francs); the Lallemand prize (I800 francs), for the encouragement of work on the nervous system; the Pourat prize (rooo francs), for a memoir on the origin of the antiferments (postponed from 1909), and (I9II) for a memoir on the influence of the mineral elements, especially of calcium, on the activity of the digestive diastases.

Statistios.-A Montyon prize (I000 francs, a mention of 500 francs).

History of Science.-The Binoux prize (2000 francs).

General Prizes.-The Arago, Lavoisier, and Berthelot medals; the Gegner prize ( 3800 francs); the Lannelonque prize (2000 francs); the Trémont prize (1 100 francs); the Wilde prize (one of 4000 francs or two of 2000 francs), for discoveries in astronomy, physics, chemistry, mineralogy, geology, or experimental mechanics; the Lonchampt prize (4000 francs); the Saintour prize (3000 francs), for work in mathematics: the Victor Raulin prize (I500 francs), for assisting the publication of works in geology and paleontology; the prize founded by Mme. la Marquise de Laplace; the Félix Rivot prize (2500 francs): the Pierson-Perrin prize (5000 francs), for a discovery in mechanics or physics; the Serres prize ( 7500 francs), for works on general embryology applied to physiology and medicine; the Jean Reynaud prize (10,000 francs), for an original scientific work; the Petit d'Ormoy prize (two prizes of ro,ooo francs), one for work in pure and applied mathematics, and one for natural science; the Baron de Joest prize (2000 francs).

\section{LONDON COUNTY COUNCIL CONFERENCE OF TEACHERS.}

SIX addresses were given from the chair and twenty papers were read at the meetings held on January 6 , 7 , and 8 at the Birkbeck College. As a rule, the gatherings were large, and the papers read were of considerable importance. We understand that the London County Council will publish and distribute a complete report with the same liberality as in former years.

The subjects of the papers were classed under the headings:-(1) organisation of higher schools; (2) training of engineers; (3) teaching of number; (4) teaching of domestic economy; (5) methods of teaching in schools for the mentally defective; (6) educational experiments in schools. With so varied a programme it is not easy to point to any single idea as dominant in the papers or in the discussions which followed. Nevertheless, it is safe to say that there was a continued endeavour, consciously in some cases and unconsciously in the remainder, to bring the No. 2098 , VOL. 82] work within the school walls into closer relation with the present and future activities of the pupils in their daily lives.

The main impression produced by the conference as a whole--an impression which could hardly escape the notice of any reflective observer-was that the London education authority is acting with wise foresight in encouraging initiative and individuality among its teachers. One cannot, of course, assume that such encouragement is given in every school simply on the evidence of these meetings but there is no doubt that men of originality and proved competence are encouraged and helped to put into practice new ideas and new methods, and that this is true for the older as well as the newer subjects of the curriculum. It is not easy to overrate the importance of the attitude of the London Education Committee and its official advisers with regard to this treatment of the teacher. Whether we approve or not, for good or for ill, the growing municipalisation of education in this country is an irresistible fact.

That the administration should be municipalised is probably a benefit; we may agree with Mr. Cyril Cobb (who opened the conference) in his view that the union of education with other municipal work was good, both for education and the other municipal departments which were brought into touch with it. The danger-and it is a grave one-is that the teachers may become bureaucratised-that they may sacrifice the finer elements of professional spirit to the attainment of smooth and trustworthy working as components of the municipal machine. If English schools are to continue to deserve their reputation for training character it can only be by retaining the requisite spirit in the teachers. . From these considerations we may regard the tone of these conferences 'as promising well for the future of London education. With thankfulness we recognise that the London County Council is anticipating the dangers which are liable to accrue from the very efficiency of its system, and is inhibiting their growth by promoting the development of initiative and of independent professional criticism among the teachers in the London service.

\section{Organisation of Higher Schools.}

Turning to the headings given above; under: (I) Mrs. Millington discussed the aims of the new Central Schools for Girls, for which the age of entry is eleven to twelve and of leaving fifteen to sixteen. Girls needed both fitness to take charge of a home and fitness for commercial or industrial employment. Training for home-making should be given to all girls alike; for this purpose a small house, a day-nursery, and a small garden should be attached to the schools. Poetry, music; and one foreign language were among the essentials. Mr. H. J. 'Spenser, headmaster of University , College: School, read a paper on the organisation of a large secondary school, in the course of which he said that, as compared with other nations, we suffered from lack of expert knowledge in our rulers. Abroad, the men who controlled national systems were men who had spent most of their lives in teaching. We pay a heavy price for amateur government. The greatest national need to-day is the need for efficiency in the secondary schools.

\section{Training of Engineers.}

The discussion on the training of engineers took place under the presidency of Sir William White, who advocated a preliminary practical training interposed between the secondary school and the technical college. It was during that period that the boy learned most from the workman, and in Germany they had gone back to that system. After Dr. Walmsley had described the "sandwich" system of training as practised by engineering students of the Northampton Polytechnic Institute at Clerkenwell, a paper was read by Prof. D. S. Capper, in which the author reviewed the whole subject. He divided an engineer's training into (r) school training; (2) scientific training; (3) technical training; (4) subsequent training. As regards (I), he deprecated specialisation, advocated freehand and mechanical drawing, and limited the usefulness of schonl workshops to teaching a boy to use his tools, to think in the solid and to realise methods of simple construction. 
Study of literature and history should balance the work in mathematics, physics, and chemistry. Modern methods of teaching mathematics in schools had produced a great improvement. After school, the factory or office training should extend over two or three years. Should a year of it be interposed between school and college, and the remainder be completed after college? Or should the summer of each year be spent in the factory and the winter in college? Twenty years' experience had shown him that the answer depended on the individual temperar ment of the student. The college course should lead to a science degree, and the technical diploma should be granted, not by the university, but by a professional body qualified to judge technical training. This training must be carried out on its "clinical" side on a commercial scale and amid commercial surroundings. With reference to the London matriculation, he pleaded for a simplification of the "English" paper and for the introduction of trigonometry in the syllabus for elementary mathematics. At whatever branch of engineering the students were aiming, they should acquire some knowledge of machinery and machine processes, and also some familiarity with the applications of clectricity-for engineering practice, not for passing an examination. Specialised professional subjects, e.g. bridge building, should be treated at the post-graduate stage.

\section{Domestic Economy.}

Mr. J. Wilson (Battersea Polytechnic) delivered an address on the correlation between the teaching of domestic economy and experimental science. The practical problems are how to link the chemistry and physics to the domestic subjects, and how to teach the latter, so far as possible, as applied science. Should the experimental science and the domestic subjects be fused together into one subject? After an experience of ten years at Battersea, the lecturer gave it as his opinion that they should remain two distinct but correlated branches of study. At present the proper teaching of the science subjects on the one hand, and the domestic subjects on the other, demands a specialist mistress for each group. There must be frequent consultation between the two teachers to ensure proper coordination. The principles to be followed were illustrated by detailed discussion of the following typical course for a girls' secondary school (some nature-study should precede the course) :-

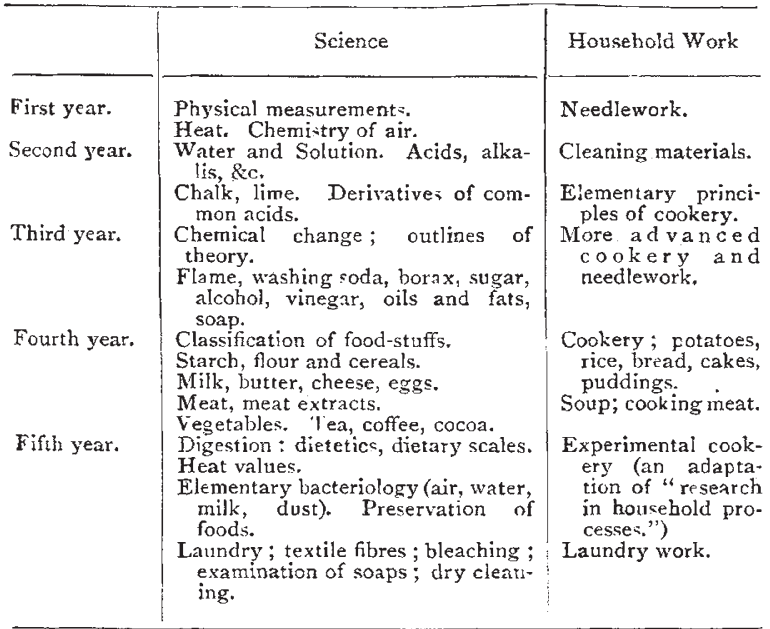

Generally speaking, the girls feel that the work is of direct value to them, and the course proves to be as truly educational as the older courses of systematic chemistry and physics, although the problens studied are much more complex. With the present regulations for matriculalation, girls who enter for this examination cannot take the fourth or fifth year's course. Mr. Wilson suggested that the London University and the Joint Scholarships Board should add a suitable syllabus which would allow candidates to follow such a course as the one outlined.

Sir Lauder Brunton, who presided, and the Hon. Mrs. NO. 2098, VOL. 82]
Bertrand Russell, dealt with the social aspect of the subject, and it was pointed out that the comfort, health, and sobriety of the nation depended to a great extent on efficient and widespread teaching of domestic economy.

\section{Other Subjects.}

The initiated are aware that the teaching of number is of far greater importance than is generally supposed, and will learn without surprise that a whole session was devoted to that topic. Mr. T. Raymont (Goldsmiths' College) opened with an exposition of fundamental principles. The fifth meeting was devoted to problems connected with mentally defective children, and there was a small exhibition of work accomplished, which served to illustrate the methods of teaching in some of the council's special schools.

The final meeting was in many respects the most important and encouraging of the series organised by Dr. Kimmins. Under the title "Educational Experiments in Schools " was given the clearest evidence of the abilities of the teachers and of the opportunities afforded them to develop their ideas. Mr. E. White, handicraft instructor at Essendine Road, gave a lucid account of the manner in which the work of his handicraft centre had been coordinated with that of the schools connected therewith. A sound start was made by bringing the class-teachers into closer relation with the instructor. The council's inspectors and H.M. inspectors gave help, with the result that arithmetic, nature-study, science, and in a lesser degree composition, geography, and history, were all benefited by the connection established between these subjects and the manual work. Mr. J. S. Fowler showed how to treat "weather study" so that its real import. ance and interest were grasped by boys, and $\mathrm{Mr}$. A. Beaves dealt in a practical way with locai history. Miss C. von Wyss gave much-needed advice upon the care of animals in schools. Teachers who wish to keep their furred, feathered, or finned pets in good health should read this paper in the coming report. Incidentally, they will, it is to be hoped, both imbibe themselves and infuse into their pupils that spirit which prompts " courtesy to tadpoles."

G. F. D

\section{ELECTRIC VALVES}

NOW that the use of higher voltages for bulk supply is becoming more general in this country, the ques tion of protection of electrical plant against damage due to resonance surges in underground lines and atmospheric disturbances as well as in overhead lines-which for commercial reasons are likely to become more common in the near future-is one that electrical engineers should turn their attention to at the present time.

Where trouble has already occurred in central station it has generally been put down to faulty design or bad insulation of the machines. There is no doubt, however, that the damage is caused very often by the setting upowing to a short circuit or the sudden action of the automatic fuse-of a serious rise of potential, which is stored in the windings of the alternator, and can only flow off through the capacity of the transformer or by perforating the insulation. Such voltages rapidly deteriorate the insulation of sunk windings, and so it becomes necessary to find some means of overcoming this difficulty. Two such pieces of apparatus are now available, and may be used in conjunction with each other or separately, according to the conditions controlling the line, area of distribution, capacity of plant, \&c., and are known as the "electric valve" and "Moscicki condenser."

The electric valve consists of a number of spark-gaps arranged as follows. The first spark-gap is placed in series with a sufficiently high resistance, so as to avoid high-frequency oscillations, and the remaining spark-gaps are indirectly connected to earth through small condensers, the last spark electrode being connected direct to earth. The spark-gaps are formed between the edges of sharp round discs of non-arcing metal insulated from each other and from the earth connection. The capacity required is obtained by these discs and a central rod which is connected to earth, and also acts as a support for the discs 